Cad.Est.Ling., Campinas, (44):119-132, Jan./Jun. 2003

\title{
ANÁFORAS ASSOCIATIVAS ACTANCIAIS E NOMINALIZAÇÕES: DELIMITAÇÃO DO PONTO DE VISTA DA SEMÂNTICA DE EVENTOS
}

\author{
GRAZIELA ZAMPONI \\ (FAENQUIL/FATEA)*
}

\begin{abstract}
This paper presents some distinction between actancial associative anaphora and nominalisation from semantics of events. We claim that if the anaphoric element plays a thematic role of the previous sentence, an actancial associative anaphora will occur; if the anaphoric element refers to an argument describing the event of the verb, it will be considered a nominalisation.
\end{abstract}

\section{INTRODUÇÃO}

Esta pesquisa examina, da perspectiva da semântica de eventos, dois tipos de anáforas: a anáfora associativa actancial (de acordo com a tipologia de Kleiber, 2001) e a nominalização. Acreditamos ser possível traçar uma distinção entre essas anáforas a partir dos argumentos que saturam uma posição argumental previsível, relativa ao evento descrito pelo verbo da sentença anterior. Examinando o fenômeno por esse ângulo, podemos hipotetizar que, se o anafórico funciona como um argumento que preenche um papel temático predizível na sentença anterior, trata-se de uma anáfora associativa actancial; se o anafórico refere o evento descrito pelo verbo ( \pm argumento(s)) da sentença anterior, trata-se de uma nominalização.

Essa hipótese sustenta-se na tese de Chierchia (1997), de acordo com a qual o verbo não só determina papéis temáticos, mas também descreve eventos. Assim, além dos argumentos explícitos que preenchem os papéis temáticos, o autor postula um argumento implícito, denominado argumento-evento ${ }^{1}$, elemento fundamental para nossa tentativa de estabelecer a distinção semântica entre os dois tipos de anáforas aqui focalizados.

A autora é professora da Faculdade de Engenharia Química de Lorena (FAENQUIL) e das Faculdades Integradas Teresa D'Ávila (FATEA) - Lorena-SP, e doutora em Lingüística pela UNICAMP.

${ }^{1}$ Chierchia (1997), na classificação das classes acionais, usa o termo 'evento' para os verbos de acontecimento que envolvem um ponto de culminação intrínseco, um "telos" (p. ex., chegar), e o termo 'processo' para os verbos de acontecimento que não têm um ponto de culminação inerente, mas podem ser interrompidos a qualquer momento ou prolongados indefinidamente (p. ex., caminhar); desse modo, os eventos são télicos e os processos, atélicos. Ele ainda distingue os verbos de acontecimento e verbos de estado. Como essa distinção não é significativa para os nossos propósitos, não a levaremos em conta. 
O verbo encontrar, por exemplo, apresenta uma relação de três lugares entre encontros e indivíduos que são protagonistas de encontros. Em (1),

(1) Léo encontrou Hugo.

esses lugares são preenchidos por "Léo" (argumento que satura o papel temático de agente), "Hugo" (que satura o papel temático de tema) e "encontro" (argumento implícito que constitui o argumento-evento.) Desse modo, (1) tem as mesmas condições de verdade que

(2) Ontem ocorreu um encontro de Léo e Hugo.

de forma que (2) faz de maneira explícita o que (1) faz de maneira implícita: descrever um evento de um certo tipo, um encontro entre indivíduos.

$\mathrm{O}$ interesse pela anáfora deve-se ao papel fundamental que esse mecanismo desempenha na construção textual-discursiva, o que lhe garante um lugar de destaque nos estudos lingüísticos.

A literatura sobre as anáforas nominais é vasta e rica; várias são as respostas teóricas e diversas as abordagens que buscam fornecer uma descrição do fenômeno. Assim, diferentes são as veredas trilhadas. Nesta pesquisa, limitamo-nos a um tratamento semântico da anáfora, que não levará em conta, na medida do possível, o viés discursivo. Trata-se de um recorte teórico, que não tem a pretensão de constituir uma resposta definitiva - se é que existe alguma - para uma tipologia das anáforas.

A anáfora constitui um mecanismo de relação entre um elemento que exige saturação referencial ("elemento anafórico", "expressão anafórica" ou "anafórico") e um elemento antecedente, que fornece as condições para que essa saturação seja satisfeita. Desse modo, toda anáfora implica uma atividade de remissão, já que põe em jogo um ato de "apontamento" para um elemento, normalmente presente no co-texto, e possivelmente de retomada, pois, havendo ou não identidade material entre os elementos envolvidos, a anáfora é, em geral, responsável pela continuidade referencial. Mas isso não significa que a anáfora se limite a funcionar como um mecanismo de manutenção referencial; ela constitui também um poderoso recurso de progressão discursiva; ao mesmo tempo em que remete e/ou retoma, opera uma progressão referencial, estando assim indissociavelmente ligada à dinâmica textual-discursiva. $\mathrm{Na}$ sua atividade de remeter, o elemento anafórico pode reativar referentes introduzidos anteriormente (anáfora direta) ou ativar um novo referente, cuja interpretação depende de dados previamente introduzidos (anáfora indireta).

De maneira geral, são apontados vários tipos de anáforas, embora não sem um certo "conflito", porque existe uma acentuada diversidade de critérios que servem de base às diferentes tipologias. Assim é que, por exemplo, 'anáfora co-referencial' e 'anáfora não co-referencial' são tipos determinados pela identidade ou não dos referentes envolvidos no processo; 'anáfora fiel' e 'anáfora infiel', pela repetição ou substituição do lexema que retoma o antecedente; 'anáfora segmental' e 'anáfora redutiva', como postula Maingueneau (2001), pelo tipo do antecedente, um grupo nominal ou um fragmento de nível pelo menos igual à frase, respectivamente. 
Como foge aos limites desta pesquisa uma discussão sobre esse 'cipoal' terminológico e conceitual, definimos anáfora associativa e nominalização como segue.

\section{ANÁFORA ASSOCIATIVA E NOMINALIZAÇÃO: BREVE DEFINIÇÃO}

A anáfora associativa apresenta as seguintes propriedades:

- $\quad$ refere-se a uma entidade que, embora apresentada como já conhecida, é nova no discurso; não há, pois, na anáfora associativa uma relação de coreferencialidade;

- pode ser interpretada referencialmente somente em relação a dados introduzidos anteriormente no universo de discurso, propriedade que justifica o termo 'anáfora'.

É o que ocorre em (3), em que o sintagma destacado, apresentado no modo conhecido, é interpretado referencialmente em relação a "uma fazenda sem vida".

(3) Estavam no pátio de uma fazenda sem vida. O curral deserto, o chiqueiro das cabras arruinado e também deserto, a casa do vaqueiro fechada, tudo anunciava abandono. (Ramos, Graciliano. Vidas Secas.)

Um exame profundo da anáfora associativa, da perspectiva semântica, é feito por Kleiber (2001), cuja concepção localiza na língua a relação entre os dois termos envolvidos na associação anafórica; para ele, a ligação entre os dois elementos é préinscrita no léxico sob a forma de um traço necessário ou estereotípico. Daí a sua fórmula: "a anáfora associativa rola sobre estereótipos".

Normalmente, os casos canônicos da anáfora associativa envolvem a relação parte-todo (relação de meronímia), como o mostra o exemplo (3): 'curral' é (geralmente) parte de 'fazenda'. Embora a solução meronímica tenha a vantagem de abrigar casos claros como o acima citado, em que se reconhece sem dificuldade uma relação parte-todo, isso não ocorre num encadeamento como

(4) Paulo cortou o pão e guardou a faca.

tipificado por Kleiber (2001) como anáfora associativa actancial.

$\mathrm{Na}$ anáfora associativa actancial ocorre a relação entre um antecedente na forma de um predicado - um SV (cf. exemplos (4) e (5)) ou um SN predicativo ou processual (cf. exemplo (6)) -, sendo o elemento anafórico um de seus argumentos ou actantes. A definitude da expressão provém precisamente dessa relação actancial. Kleiber (2001) sublinha que todas as anáforas associativas actanciais podem ser tratadas a partir da descrição das valências dos predicados verbais e nomes predicativos. Nesse sentido, o anafórico da relação associativa actancial satura um lugar argumental do predicado antecedente, evidentemente um lugar deixado vazio. 
(5) (...) Jam Master Jay, 37, cujo nome verdadeiro era Jason Mizell, foi morto em seu estúdio, no bairro de Queens, em Nova York, no último dia 30 de outubro, com um tiro à queimaroupa. Na semana passada, a polícia divulgou a descrição do atirador, mas, até o fechamento desta edição, não tinha pistas que levassem ao assassino ou ao motivo do crime. (FSP. Caderno Folhateen, 11/11/02, p. 6)

(6) (...) Acabar com a entrega de cestas básicas gratuitas demonstra que estamos começando a tomar consciência de que, para resolver os problemas sociais, temos de iniciar pela promoção humana, recuperando a auto-estima e a auto-valorização de cada cidadão.

Claro que há que se buscar alternativas a esse corte, mas que sejam alternativas inteligentes, que proporcionem a essas pessoas a possibilidade de participar efetivamente das relações de consumo inerentes a qualquer sociedade. (Santiago Torrente Perez, Folha de S.Paulo, $29 / 11 / 00-\mathrm{A}-3$ )

Em (4), "a faca" satura o argumento correspondente ao instrumento e em (5), "o atirador", o argumento correspondente ao agente, cujos antecedentes constituem SV; já em (6), "essas pessoas" satura o argumento correspondente ao receptor, cujo antecedente, "a entrega" é um SN processual, que comporta um nome de evento ${ }^{2}$.

A nominalização constitui um fenômeno em que um sintagma nominal transforma em referente o processo denotado por uma proposição, que, obviamente, não tinha esse estatuto anteriormente. Trata-se de uma operação que consiste em referir, por meio de um SN, a um processo ou estado que foi previamente significado por uma proposição. (cf. Apothéloz, 1995). É o que ocorre em (7)

(7) A Vigilância Sanitária do Estado de São Paulo determinou ontem que todos os produtos com suspeita de conter transgênicos em sua composição sejam recolhidos dos locais de venda em até 15 dias. A determinação cumpre uma lei estadual de dezembro de 1999. (FSP, 2/08/00, A-14)

em que o anafórico “a determinação" explicita o evento descrito pelo verbo da proposição anterior, constituindo, como postulamos, um argumento-evento.

\section{ANÁFORA ASSOCIATIVA ACTANCIAL E NOMINALIZAÇÃO À LUZ DE EVENTOS E PAPÉIS TEMÁTICOS}

Chierchia (1997) desenvolve a tese de que o verbo descreve um evento cujos argumentos desempenham papéis específicos, os chamados papéis temáticos, velhos conhecidos dos semanticistas. Considerando apenas essa dimensão, dizemos que a sentença (1) é interpretada como em (1'), conforme aponta Chierchia:

(1) Léo encontrou Hugo

(1') Há um evento tal que

i. esse evento é um encontro

${ }^{2}$ Um N eventivo pode ser descrito formalmente como um predicado que possui uma ou mais posições de argumento. Desse modo, "entrega" poderia ser assim representado em seu valor de processo:

entrega $(\mathbf{x}, \mathbf{y}, \mathbf{z})=$ alguém $(\mathbf{x})$ entrega qualquer coisa $(\mathbf{y})$ a alguém $(\mathbf{z})$ 


\section{ii. o encontro é de Hugo por Léo (Léo= agente; Hugo= tema)}

Segundo Ilari (2001:131), os papéis temáticos mais comuns são ${ }^{3}$
a. Agente
(o indivíduo que tem a iniciativa da ação, que tem controle sobre a ação)
b. Alvo/tema
c. Instrumento
(o indivíduo ou objeto diretamente afetado pela ação)
d. Beneficiário
(o objeto de que o agente se serve o agente para praticar a ação)
e. Experenciador
(o indivíduo a quem a ação traz proveito ou prejuízo)
(o indivíduo que passa pelo estado psicológico descrito pelo verbo)

Além desses, Chierchia (1997) apresenta ainda
f. Receptor
(o indivíduo que recebe o objeto afetado pela ação)
g. Origem (o indivíduo de quem procede algo)
h. Localização
(o local em que ocorre a ação) ${ }^{4}$

Segundo esse autor, a introdução dos eventos torna mais explícito o tratamento dos papéis temáticos, que, como vimos, são encarados como relações entre os eventos e seus protagonistas. Assim, a relação de agente é uma relação entre um evento (e) e um indivíduo $\mathbf{x}$, em que $\mathbf{x}$ é justamente o indivíduo que causa diretamente o evento; a relação de tema é uma relação em que $\mathbf{x}$ é afetado por e, e assim por diante ${ }^{5}$. Podemos, pois, assim definir essas duas relações:
a. $\quad \mathbf{A G}(\mathbf{e}, \mathbf{x})=\mathbf{x}$ é o agente de $\mathbf{e}$
b. $\quad \mathbf{T E}(\mathbf{e}, \mathbf{x})=\mathbf{x}$ é o tema de $\mathbf{e}$

Devido à vagueza das definições dos papéis temáticos, ${ }^{6}$ é necessário buscar um mecanismo capaz de superar esse problema. Chierchia (1997) encontra nas preposições

3 Fillmore (1968), embora de uma perspectiva diferente, a da gramática gerativa, postula que a sentença, em sua estrutura básica, consiste em um verbo e um ou mais sintagmas nominais, cada um associado ao verbo numa determinada relação de caso, cuja noção inclui um conjunto de conceitos universais, presumivelmente inatos. Entre os casos mais comuns, aponta Agentivo, Instrumental, Dativo, Factivo, Locativo e Objetivo. Seria interessante um estudo mais detido desse autor, a nosso ver, injustamente ignorado nas abordagens que se fazem sobre os papéis temáticos.

${ }^{4}$ Outros autores ainda propõem outros papéis temáticos. Vilela e Koch (2001), por exemplo, apresentam um papel temático de posicionador, próprio de verbos como ficar, estar em, encontrar-se em, que implicam um actante designado de "situativo".

${ }^{5}$ Ressalte-se que os papéis temáticos são distintos das funções sintáticas, embora seja possível haver coincidência entre eles.

${ }^{6}$ Por exemplo, na sentença "Hugo chegou", "Hugo" pode ser o agente ou o tema, se se entender que ele é a causa direta do evento, realizando a ação voluntariamente, ou o alvo da ação, se, independentemente 
um instrumento para que dê conta dessa tarefa. ${ }^{7}$ Assim, "por (parte de)", "de", "para" caracterizam os papéis de agente, tema e receptor, respectivamente (Chierchia, 1997). E acrescentamos: "em" e "com" para localização e instrumento, respectivamente.
a. $\quad \mathbf{A G}(\mathbf{e}, \mathbf{x})=\mathbf{e}$ é por $($ parte $)$ de $\mathbf{x}$
b. $\quad \mathbf{T E}(\mathbf{e}, \mathbf{x})=\mathbf{e}$ é de $\mathbf{x}$
c. $\quad \mathbf{R E}(\mathbf{e}, \mathbf{x})=\mathbf{e}$ é para $\mathbf{x}$
d. $\quad \mathbf{L O}(\mathbf{e}, \mathbf{x})=\mathbf{e}$ é em $\mathbf{x}$
e. $\quad$ IN $(\mathbf{e}, \mathbf{x})=\mathbf{e}$ é $\operatorname{com} \mathbf{x}$

Chierchia (1997) aborda a questão dos nomes eventivos quando trata das nominalizações, restringindo esse fenômeno ao domínio dos deverbais, cuja principal característica é fazer referência, diretamente, a eventualidades; derivando de um verbo, o deverbal ( \pm complemento/modificador) permite saturar todos os argumentos desse verbo, exceto o argumento-evento. E aqui se vê a utilidade dos papéis temáticos na caracterização semântica dos nomes derivados. Tomemos o exemplo (8):

(8) Na edição de ontem, a Folha informou que o procurador Cyril Whelan, de Jersey, proferiu parecer favorável ao envio da documentação bancária ao Ministério da Justiça brasileiro. (FSP., 20/02/03, A-13)

Sintaticamente, “da documentação bancária” e "ao Ministério da Justiça brasileiro" ocupam a posição de complemento de "envio". Semanticamente, os dois SP desempenham os papéis de tema e receptor, respectivamente; os mesmos papéis desempenhariam se completassem o verbo "enviar", o que revela os nexos semânticos entre os verbos e suas nominalizações. Se há equivalência de papéis temáticos dos verbos e dos nomes deles derivados, podemos afirmar que "envio da documentação bancária ao Ministério da Justiça brasileiro" e "enviar a documentação bancária ao Ministério da Justiça brasileiro" são c-sinônimas; a diferença é que na frase verbal, a referência ao evento permanece implícita; na nominal, ela é explicitada.

Um outro aspecto é bastante interessante à luz do que nos propomos a examinar. Trata-se obrigatoriedade ou não da saturação de uma posição argumental. Enquanto nos verbos, que exprimem relação, os papéis temáticos são quase sempre obrigatórios, nos nomes isso não ocorre. Desse modo, (9) é bem formada, mas (10) não:

(9) $\operatorname{ENVIO}(\mathbf{e})$

(10) ENVIAR (e,

de sua vontade, é levado a um local. Neste caso, o argumento pode ser caracterizado como tema que também tem um caráter de agente, acumulando, portanto, os dois papéis.

7 Todavia, deve-se levar em conta que, se os papéis temáticos podem ser tomados como universais, isto é, como aparato semântico da gramática universal, o mesmo não se pode dizer das preposições que, além de polissêmicas, não têm o mesmo valor em todas as línguas; e mais: as preposições podem indicar papéis diferentes conforme a classe acional. A preposição "de", por exemplo, pode tanto indicar o tema quanto o experenciador: o cancelamento da passagem / o entendimento do aluno. (Cf. Chierchia, 1997) 
Para Chierchia (1997), isso explica a gramaticalidade de todas as construções com o nome, e a agramaticalidade de algumas com o verbo correspondente:

(11) a. O empréstimo de um livro a João por parte de Maria

b. O empréstimo de um livro por parte de Maria

c. O empréstimo (por parte) de Maria

d. O empréstimo de um livro

e. O empréstimo de um livro a João

f. O empréstimo a João

g. O empréstimo ${ }^{8}$

(12) a. Maria emprestou um livro a João

b. * Maria emprestou a João

c. Maria emprestou um livro

d. * Maria emprestou

e. * Emprestou

f. Emprestou um livro 9

Como decorrência do que vimos apresentando até aqui, podemos dizer que os argumentos que desempenham os papéis temáticos são exteriores ao conteúdo do $\mathrm{V}$ ou do $\mathrm{N}$, enquanto o argumento-evento coincide com o conteúdo de V. É nisso que nos apoiamos para justificar a distinção entre a anáfora associativa actancial e a nominalização: se, por um lado, elas partilham a propriedade de ter como antecedente um predicado, por outro, elas se diferenciam no tipo de tipo de posição argumental que o elemento anafórico satura. Explicitando melhor: o anafórico da anáfora associativa actancial satura uma posição argumental externa ao conteúdo do verbo ou do nome, desempenhando um papel temático, enquanto $\mathrm{o}$ anafórico do processo de nominalização constitui o argumento-evento que coincide com o conteúdo do predicado de uma sentença anterior.

Os exemplos abaixo mostram alguns casos de anáfora associativa actancial:

(13) Durante debate recente em uma Universidade, nos Estados Unidos, o ex-governador do Distrito Federal, Cristovam Buarque do PT, foi questionado sobre o que pensava da internacionalização da Amazônia. O jovem introduziu sua pergunta dizendo que esperava resposta de um humanista e não de um brasileiro.(...) (O Globo, 23/10/00)

(14) Editoras aproveitam o Fórum Social para lançar obras ligadas aos protestos antiglobalização. A Coleção Baderna e outros livros refletem o pensamento desses grupos. (FSP, 30/1/02,A-1)

(15) Quatro ou cinco cavalheiros debatiam, uma noite, várias questões de alta transcendência, sem que a disparidade dos votos trouxesse a menor alteração aos espíritos. A casa ficava no morro de Santa Teresa, a sala era pequena, alumiada a velas, cuja luz fundia-se misteriosamente com o luar que vinha de fora. (Machado de Assis. O Espelho)

${ }^{8}$ Julgamos que (11g) e, talvez, (11c) e (11f) só são aceitáveis em função do co-texto. Em todos esses casos, está ausente o tema, argumento obrigatório no nível da frase, como vemos em (12).

${ }^{9}$ A gramaticalidade de (12f) deve-se ao fato de o português ser uma língua de sujeito nulo, conforme observam os tradutores de Chierchia (1997). Mas aqui também observamos que, a nosso ver, esse caso só seria aceitável em função do co-texto. 
(16) Paulo está cavando. $\mathbf{O}$ buraco já tem um metro de profundidade, mas há problemas com a pá.

Em (13) e (14), os anafóricos desempenham papel de agente; em (15), de locativo; em (16), de tema e instrumento, respectivamente. Essas construções, bastante comuns, podem ser assim formalizadas (os argumentos sublinhados constituem os argumentos ausentes das sentenças que funcionam como antecedentes dos anafóricos):
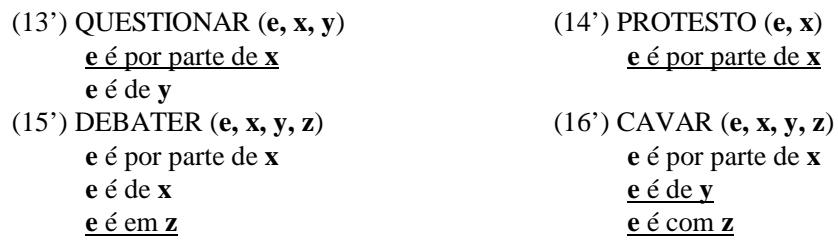

Se casos como esses - resolvidos por uma rotina anafórica banal - não oferecem qualquer desafio de análise de acordo com nossa perspectiva, o mesmo não se pode dizer de

(17) Grupos religiosos passaram a ver nessas emissoras uma boa maneira de fazer proselitismo religioso. Outras pessoas vendiam anúncios e espaço de programação com a alegação de que esse dinheiro cobria os custos operacionais. (Jornal de ComunicAção, n. 1, março/2002, p.6)

(18) Ele ficou desempregado e aceitou mal essa decadência. (Exemplo emprestado de Apothéloz e Reichler-Béguelin, 1999)

(19) Um gordo gato branco, que pertencia ao jardineiro, saltou sobre os meus joelhos e, com esse impacto, fechou o livro que tinha posto de lado para acariciar o animal (exemplo emprestado de Apothéloz , 1995)

(20) Dizem que rico, quando rouba, não é ladrão. É cleptomaníaco. Quando é rico e famoso, então... é doido de pedra, mesmo. Pois desde que Winona Ryder foi pega roubando na Sacks (uma loja superchique gringa), não conseguimos parar de acompanhar esse julgamento. (FSP. Caderno Folhateen, 11/11/2002, p. 10)

que parecem não poder ser explicados pelos papéis temáticos com que vimos trabalhando até aqui. Mas antes devemos refletir se se trata realmente de anáforas associativas. Primeiramente, vemos que as entidades dos SN destacados, embora novas, são apresentadas no modo do conhecido. ${ }^{10}$ Além disso, sua interpretação é dependente de informações introduzidas pelas sentenças anteriores, o que caracteriza a anáfora. E, finalmente, os antecedentes constituem SV e o $\mathrm{N}$ do SN anafórico aponta para uma entidade exterior ao conteúdo do V. Mas falta ainda uma tarefa: ver em que medida essas anáforas constituem um argumento do predicado antecedente.

Em (17), o argumento "esse dinheiro" está incorporado ao verbo "vender", sendo um de seus traços semânticos constitutivos. "Vender" significa transferência definitiva

${ }^{10}$ Pelo menos ele é conhecido do locutor, embora não seja necessariamente conhecido do interlocutor. É importante observar que os anafóricos constituem SN demonstrativos. No entanto, como foge aos limites desta pesquisa, não abordaremos a questão do estatuto do demonstrativo nas expressões referenciais. 
de posse de algo a alguém por meio de dinheiro. Se se trata de transferência definitiva, mas sem a contraparte do dinheiro, o verbo correspondente é "dar".

Segundo Vilela e Koch (2001:69), argumentos incorporados ao verbo geralmente não são realizados discursivamente e, quando o são, muitas vezes são acompanhados de um modificador. Mas essa observação diz respeito à relação verbo/argumento de uma mesma sentença. No nosso caso, trata-se de duas sentenças, em que o SN "esse dinheiro" é interpretado em relação às informações anteriores. Se assumíssemos estar diante de uma anáfora associativa actancial, que papel temático desempenharia o anafórico? Tratar-se-ia realmente de um papel temático, uma vez que o SN está incorporado à significação do verbo? Seria possível formalizar a valência do verbo "vender" apresentando, além dos papéis de "agente, tema e beneficiário", o que chamaríamos de "papel temático de meio"?

Essa solução, à primeira vista, não parece viável, já que, se construíssemos

(17') (?) Eles vendiam por dinheiro anúncios e espaço na programação,

estaríamos diante de uma flagrante redundância, só desfeita se o $\mathrm{N}$ "dinheiro" fosse acompanhado de modificador. O mesmo aconteceria se tivéssemos

(21) (?) Pedro foi assassinado pelo assassino.

Mas é perfeitamente possível construir

(21') Pedro foi assassinado. $\mathbf{O}$ assassino ainda não foi encontrado.

Para (18), (19) e (20) uma explicação é mais desafiadora: "essa decadência”, "esse impacto" e "esse julgamento" constituem SN cuja interpretação se dá em relação a "ficou desempregado", "saltou sobre os meus joelhos" e "foi pega roubando na Sacks (uma loja superchique gringa)", respectivamente, o que os credenciaria, à primeira vista, como anáfora associativa actancial. Mas que papel temático desempenhariam os anafóricos?

Analisando (19), Apothéloz (1995) afirma que “esse impacto" designa a consequiência (ou uma delas) do salto do gato, evento presente na sentença anterior. Do mesmo modo, poderíamos analisar os outros dois anafóricos: é possível interpretá-los como conseqüências dos eventos anteriores. Com efeito, podemos assim raciocinar: ficar desempregado causa decadência; saltar sobre algo causa impacto; ser pego roubando leva a um julgamento. Se assim considerarmos, poderíamos pensar "um papel temático resultativo"? Mas, acima de tudo, uma questão: haveria uma base semântica para tal?

Em primeiro lugar, devemos ponderar que os elementos envolvidos nos três casos são ontologicamente congruentes: trata-se de uma expressão anafórica, cujo $\mathrm{N}$ explicita um evento que tem sua interpretação garantida por um antecedente também eventivo.

${ }^{11}$ Koch (1983) postula, com Fillmore, um caso de instrumento ou meio. 
No entanto, o protótipo da anáfora associativa actancial põe em relação dois elementos - antecedente e anafórico - de categorias ontológicas diferentes. Não se trata da relação entre dois eventos, mas da relação entre um acontecimento, ação ou processo, ou seja, um evento, e o indivíduo nele implicado. (cf. Kleiber, 2001:336)

Em segundo lugar, os eventos presentes nos anafóricos não saturam um lugar argumental que permaneceria vazio na sentença anterior, determinado pela valência verbal. Efeitos ou conseqüências de ações, ao menos nesses casos, não são previsíveis no antecedente e, portanto, não poderiam desempenhar um papel temático.

Esses dois argumentos, a nosso ver, são bastante poderosos para que não consideremos como anáfora associativa actancial casos em que o elemento anafórico constitui um evento que explicitaria o efeito ou a consequiência da ação ou processo anterior. Mas é preciso alargar ainda mais essa nossa subclasse de anáfora, focalizando casos em que o anafórico está associado a um predicado antecedente, sem, no entanto, constituir um evento nem desempenhar um papel temático:

(22) [...] É preciso avisar o presidente argentino que o modelo dito de conversibilidade (o peso atrelado ao dólar) morreu. O obituário está, aliás, dia sim, outro também, em todos os jornais, brasileiros e internacionais. (Clóvis Rossi, FSP, 7/12/2001, A-2)

(23) Uniram-se os três. convivência trouxe intimidade. Pouco depois morreu a mãe de Camilo, e nesse desastre, que o foi, os dous mostraram-se grandes amigos dele. Vilela cuidou do enterro, dos sufrágios e do inventário; (...) (Machado de Assis. A Cartomante)

Os SN destacados constituem anafóricos associativos, cujo antecedente se encontra em "morreu”, ou não dependeriam referencialmente desse predicado, uma vez que em si mesmos já contêm o traço 'morte'? Se adotássemos a segunda alternativa, não haveria anáfora e seria difícil explicar a definitude dos SN, que só podem ser saturados referencial em relação à sentença precedente. Aparentemente fenômeno semelhante ocorre em (24):

(24) Os mais poderosos, os mais ricos, os mais influentes estavam lá. De queixo caído. O casamento de Jacob Safra, filho do banqueiro Joseph Safra, com Michele Kamkhagi foi uma festa nunca antes vista em São Paulo. (...) Na sinagoga, segurança máxima, detectores de metal. [...]

\section{O CENÁRIO}

(...) Da sinagoga para a festa. (...) Os pais recebiam na entrada. Por perto, Giovanni, o cabeleireiro de Vicky. Atento para qualquer fio de cabelo dela que saísse do lugar.

\section{O PODER}

Os convidados mostravam um cartão magnético onde era colado um adesivo com o lugar do salão que lhes cabia. (...) (FSP, 16/11/2001)

Como interpretar o SN “os convidados”? Para Kleiber (2001), não se trata de uma anáfora actancial (cujo antecedente é "o casamento”, nome eventivo), já que esse SN não desempenha o papel de argumento ou actante. Se o conceito de anáfora associativa actancial está restrito a argumentos saturados por anafóricos que desempenham determinados papéis temáticos, temos de concordar com o autor. 
Mas a pergunta persiste: como classificar esses tipos de anáforas associativas? Uma explicação poderia encontrar apoio nos conceitos de ingrediência e de cenário ${ }^{12}$. Mas, como essa hipótese se encontra além dos limites desta pesquisa, deixamos sua análise para trabalhos futuros, sugerindo de antemão que se reserve uma outra denominação a essas anáforas e hipotetizando que aí poderia residir em parte a diferença entre anáfora associativa e anáfora indireta, como postulam vários autores.

Também as nominalizações não estariam a salvo de questionamentos. De acordo com a nossa hipótese, constitui uma nominalização a relação em que o anafórico refere o evento descrito pelo verbo ( \pm argumento(s)) da sentença precedente, como vimos no exemplo (7).

No entanto, devemos levar em conta alguns processos em que o anafórico não deriva morfologicamente do verbo da sentença que lhe serve de antecedente (caso denominado supletismo), mas que, sem dúvida, somente é saturado referencialmente em relação a essa sentença, operando um encapsulamento, o que confere ao processo um caráter resumitivo e/ou rotulador/categorizador. É o caso de (25) - (28):

(25) O Iraque anunciou na semana passada a suspensão de suas exportações de petróleo por um prazo de 30 dias, como forma de protestar contra a atual ofensiva militar israelense nos territórios palestinos. A ação provocou uma imediatamente (sic) alta nos preços do produto no mercado internacional. (FSP. Folhateen, 15/04/2002, p. 11)

(26) Dezenas de ônibus levarão alunos e professores para trabalhar em favelas e outros locais de concentração de populações de baixa renda, onde tenha sido identificada previamente a existência de brasileiros marginalizados pelo analfabetismo. Esse levantamento já foi iniciado, na capital paulista. (FSP, 20/02/2003, A-5. Informe publicitário da UniFMU)

(27) "Os únicos países que parecem estar enfrentando a queda global - Índia, China e Rússia e alguns do Leste Europeu - são os que resistiram à completa integração na economia mundial, retendo vestígios de socialismo e de mercados protegidos."

No ambiente maniqueísta em que se dá boa parte do debate no Brasil, Pearlstein seria logo acusado de perigoso comunista. Para os brasileiros que acham que só preto e branco no mundo, quem ousa dizer que é possível se dar bem sem se render por inteiro aos mercados só pode ser um bolchevique daqueles. É uma tolice, mas muito forte no país.

O diabo é que as coisas são mais complicadas do que esse Fla-Flu ideológico. (...) (Clóvis Rossi, A escolha do Brasil. FSP, 8/11/2001 - A2)

(28) Ontem o secretário de Estado de Bush, Colin Powell, e outros assessores menores foram à mídia dizer que Sharon havia entendido o recado de Bush. As tropas de Sharon deveriam parar "já". Isto é, assim que fosse possível, pois exércitos não se retiram de uma hora para outra, Bush "não pode dar ordens" a outro chefe de Estado etc. Enfim, a pantomima toda era para mitigar a impressão geral de cumplicidade de Bush no caso. (Vinícius Torres Freire, FSP, 8/4/2002, A2)

Salta aos olhos que, se, por um lado, todos esses casos partilham a propriedade de os anafóricos serem interpretados referencialmente somente em relação ao todo

12 Para Kleiber (2001), esse modo de considerar as anáforas associativas é vago quanto ao que recobre exatamente a relação entre o referente do elemento anafórico e o cenário antecedente, o que possibilita assimilações não desejáveis e não permite destacar qual é o papel precisamente desempenhado pelo cenário nas anáforas associativas. No entanto, o autor ainda não forneceu um tratamento semântico do fenômeno. Já Berrendonner (1995) trata a anáfora associativa não só como uma relação processo-actante, mas também uma relação de componentes de cenários, considerando-os uma variedade de ingrediência. 
anterior, referindo ao(s) evento(s) precedente(s), por outro, esses elementos apresentam estatutos diferentes.

Em (25), "a ação" refere o anúncio do Iraque quanto à suspensão de suas exportações de petróleo, constituindo um hiperônimo desse evento. Em (26), "esse levantamento" refere a identificação prévia da existência de brasileiros marginalizados pelo analfabetismo. Esses dois casos têm em comum o fato de os dois $\mathrm{N}$ serem predeterminados semanticamente: 'anunciar' é realizar uma ação; identificar previamente a existência de algo é possivelmente parafraseável por 'realizar um levantamento'.

Mas em (27) e (28) testemunha-se claramente um processo de recategorização metafórica dos eventos, processo que os qualifica de modo pouco predizível, em nome de uma intenção argumentativa por parte do produtor do texto. Seria prudente considerar como nominalizações apenas os casos em que o anafórico refere o argumento-evento seja por uma nominalização derivada morfologicamente, seja por um hiperônimo, seja ainda por um nome que pode parafrasear a sentença precedente? $\mathrm{Ou}$ poderíamos considerar todos sob o mesmo rótulo, a partir da aceitação de que o indivíduo pode escolher elementos lexicais variados para operar uma sinonímia tributária do discurso?

Para introduzir nossa reflexão, comecemos com uma consideração a respeito do próprio termo 'nominalização'. Do ponto de vista morfológico, ele significa o processo de derivação de um nome a partir de um verbo, o que justifica o termo "deverbal". Do ponto de vista textual-discursivo, o termo é usado para designar a operação discursiva de natureza anafórica em que um nome ou pronome transforma em entidade uma proposição anterior. Mas, ainda dentro desta perspectiva, o termo pode também indicar o lexema utilizado como núcleo da expressão que marca a operação anafórica ${ }^{13}$. Como se vê, aqui não está envolvida apenas uma questão de ordem terminológica, mas também conceitual, já que podemos identificar, ao menos, duas diferentes concepções do fenômeno: uma semântica, que trata o fenômeno do ponto de vista do léxico, e outra textual-discursiva, que abriga sob rótulo 'nominalização' a designação de um processo por meio de um nome, tributário, não sendo obrigatório que ele seja morfologicamente derivado de um morfema verbal ou constitua um hiperônimo desse processo.

Se, como hipotetizamos, a nominalização constitui tipo de anáfora em que o anafórico explicita o argumento-evento da sentença antecedente, devemos considerar que nesse processo estariam envolvidos SN cujo nome núcleo já estivesse predeterminado na significação do verbo ( \pm argumento(s)). Nesse sentido, então, apenas consideraríamos como nominalizações as anáforas realizadas por deverbais, hiperônimos ou nomes que possam constituir paráfrases semanticamente predizíveis do

${ }^{13}$ Essa questão é abordada por Apothéloz (1995) e Apothéloz e Chanet (1997) que, para distinguir as noções de processo e expressão anafórica, propõem o uso de "nominalização" para designar a operação discursiva e o uso de "informação-suporte" e "substantivo predicativo" para designar os elementos lingüísticos envolvidos no processo, respectivamente, a proposição objeto da nominalização e o lexema utilizado como núcleo do SN anafórico. A noção de "substantivo predicativo" é semântica e não morfológica. 
significado da sentença precedente. Além dessa restrição, parece pertinente apontar que, contrariamente ao que ocorre na anáfora associativa actancial, antecedente e anafórico possuem o mesmo estatuto ontológico, o que parece ser um traço característico desse processo.

Para os casos em que ocorre uma recategorização (muitas das vezes, metafórica) do processo, nos quais os anafóricos, na sua função de designar/referir um processo, ainda rotulam de forma pouco previsível o conteúdo do antecedente, preferimos sugerir outra designação: nomeação (como propõe Cavalcante, 2001) ou anáfora nominalizante. Provisoriamente essa solução parece viável. Neste caso, inclusive, é possível que o anafórico não constitua um evento, o que poderia ser um importante ponto de distinção. É o que vemos em (28), em que "pantomima" a rigor não constitui semanticamente um evento, embora, no contexto, assuma esse estatuto.

\section{CONCLUSÃO}

Pelo exposto, podemos concluir provisoriamente que, do ponto de vista da semântica de eventos, a anáfora associativa actancial consiste em

uma relação entre um antecedente - um evento, na forma de um SV ou SN processual - e um anafórico, incorporado ou não à significação do $\mathrm{V}$ ou do $\mathrm{N}$, que satura um lugar argumental deixado vazio na sentença anterior.

A anáfora associativa actancial apresenta as seguintes características:

- $\quad$ o argumento preenchido pelo anafórico é predizível pelo verbo da sentença anterior;

- o anafórico é exterior ao conteúdo do verbo;

- $\quad$ os elementos envolvidos possuem natureza ontológica diferente: antecedente = evento; anafórico = indivíduo.

Já a anáfora por nominalização, consiste em

uma relação em que o anafórico explicita o argumento-evento do verbo ( \pm argumento(s)) da sentença anterior.

A anáfora por nominalização apresenta as seguintes características:

- o anafórico descreve o conteúdo do verbo;

- os elementos envolvidos - antecedente e anafórico - possuem a mesma natureza ontológica: constituem dois eventos;

- $\quad$ o anafórico pode ser um deverbal, um hiperônimo ou uma paráfrase semanticamente predizível da sentença anterior; nesse sentido, a significação do nome-núcleo anafórico está predeterminada na significação do verbo.

Sabemos perfeitamente que estamos longe de tomar nosso estudo como uma solução definitiva (se é que existe alguma) para a distinção entre a anáfora associativa actancial e anáfora por nominalização. Além disso, nossas conclusões são provisórias; 
muita reflexão ainda deve ser feita, principalmente porque alguns questionamentos não foram aqui respondidos.

No entanto, a nosso ver, a pesquisa abre novas trilhas para a abordagem do fenômeno. Por exemplo, seria viável um estudo das anáforas associativas (em geral) e das nominalizações/nomeações pelo viés da metonímia e da metáfora? Pode-se pensar numa relação entre tipos de anáforas e gêneros de discurso? São questões para uma próxima investigação.

\section{REFERÊNCIAS BIBLIOGRÁFICAS}

APOTHÉLOZ, Denis. (1995). Nominalisations, référents clandestins et anaphores atypiques. In Berrendonner, A. \& R-Béguelin, M-J (ed.) Du syntagme nominal aux objets-de-discours. TRANEL, $23,143-173$.

APOTHÉLOZ, D. \& CHANET, C. (1997). Défini et démonstratif dans les nominalisations. In DE MULDER, Walter e Carl Vetters (eds.) Relations anaphoriques et (in)cohérence. Amsterdam: Rodopi. p. 159-86.

BERRENDONNER, Alain.(1995). Anaphore associative et méréologie. Recherches sur la philosophie et le langage. 16 , p. 81-98.

CAVALCANTE, Mônica Magalhães. (2001). As nomeações em diferentes gêneros textuais. In Cadernos de estudos lingüísticos, n. 41, p. 127-140.

CHIERCHIA, Gennaro. (1997). Semântica. Bologna: Il Mulino. Tradução de Luiz Artur Pagani, Rodolfo Ilari e Lígia Negri, a ser publicada pela Editora da Unicamp. A tradução do cap. 9 foi-me cedida gentilmente pelo Prof. Ilari.

FILLMORE, Charles J. (1968). The case for case. In Bach, E.; Harms, R.T. (org.) Universals in linguistics theory. New York: Holt, Rinehart and Wiston. Tradução: Lúcia Maria Pinheiro Lobato.

ILARI, Rodolfo. (2001). Introdução à Semântica. São Paulo: Contexto.

KLEIBER, Georges. (2001). L'anaphore associative. 1 ed. Paris: PUF.

KOCH, Ingedore V. (1983). Complemento ou adjunto? Versão revista da dissertação de mestrado "Os sintagmas preposicionados como modificadores nominais", apresentada na PUC-SP, em 1977.

MAINGUENEAU, Dominique. (2001). Análise de textos de comunicação. São Paulo: Cortez.

VILELA, Mário \& KOCH, Ingedore V. (2001). Gramática da língua portuguesa. Coimbra: Almedina. 